Walker-Smith pointed out, there have been few reports of well documented coeliac disease in non-Caucasian children. ${ }^{6}$

As the children of immigrant parents grow to be adults in Western society, we should be aware of coeliac disease among them. Nelson and others found rickets in six of 17 immigrant children with coeliac disease but did not find rickets in Caucasian children with coeliac disease in a series of over 100 cases. The two patients of $\mathrm{Dr}$ Dandona and his colleagues may explain the underdiagnosis of coeliac disease. ${ }^{7}$ The only relevant test to exclude adult coeliac disease is jejunal biopsy.

\section{B Thalayasingam}

Paediatric Unit,

Shotley Bridge General Hospital,

County Durham DH8 0NB

Smith R. Disorders of the skeleton. In: Weatheral DR, Ledingham JGG, Warrell DA, eds. Oxfor textbook of medicine. Vol 2. Oxford: Oxford

2 Anonymous. Coeliac disease in the elderly. Lancet $1984 ; \mathrm{i}: 775-6$

3 Losowsky MS. Malabsorption. In: Weatherall DJ, Ledingham JGG, Warrell DA, eds. Oxford textbook
of medicine. Vol 1. Oxford: Oxford University Press,
1983:12-92.

4 Nelson R, McNeish AS, Anderson CM. Coeliac disease in children of Asian immigrants. Lancer disease in child

5 Klipstein FA, Baker GJ. Regarding the definition of tropical sprue. Gastroenterology 1970;58:717-21.

6 Walker-Smith JA. Coeliac disease in children of Asian immigrants. Lancet 1973; i:428.

Swinson CM, Levi AJ. Is coeliac disease underdiagnosed?'Br Med $\mathscr{f} 1980 ; 281: 1258-60$.

\section{Deaths of athletes}

SIR, - The leading article by Dr Mark Harries (2 March, p 656) is disappointing on two counts. Firstly, the quoted source ${ }^{1}$ is based on "an underground report reaching the West at the end of July, just in time for the Los Angeles Olympic Games." Figures are given for death rates in Russian, German, and American Olympic medallists. However, it contains no personal details, no list of causes of death, no sex differentiation, no control population data, and no factual basis for a death rate quoted for British competitors. Its credibility is further undermined by pooling of data on both East and West German athletes and failure to relate possible earlier deaths to drugs available then rather than now.

The statement that athletes show an excess of premature violent deaths is consistent with previous studies, ${ }^{2}$ but the idea that an unidentified group of Russians have a complete record of the current life or death status of every one of 1570 non-Russian Olympic medallists since 1952 will not be credible to anyone who has practical administrative experience in organised sport in the West. In short, $\mathrm{Sir}$, the Nature source seems to be a politically inspired hoax, not a valid scientific report.

Secondly, it is unfortunate that Dr Harries omits mention of avoidable causes of death in sport. Intercurrent infections and preexisting, but ignored, cardiac symptoms feature prominently; on the broader recreational scale outdoor deaths by drowning, exposure, and mountaineering accidents outnumber a hundredfold all others. ${ }^{34}$

Finally, he does not seem to share my degree of concern at the present extent of doping in sport, with its steady escalation of hormonal interference. Drug abuse in sport knows no frontiers, but I would underline the positive steps taken-indeed largely initiated in the UK -towards eliminating sports doping. The Sports Council now spends over $£ 100000$ a year on dope detection (compared with less than $£ 50000$ on all other positive aspects of "sports medicine") and UK athletes are now required to undergo stringent antidrug monitoring as a prerequisite for internationa selection. Beyond Dr Harries's "fear of being caught" deterrent lies a far more positive acceptance of responsibility by governing bodies, which should lead to the only real long term answer to doping-erosion of the incentive to cheat.

P N SPERRYN
President, London Athletic Club

\section{New Malden,}

Surrey KT3 6NS

1 Rich V. Mortality of Soviet athletes. Nature 1984 $311: 402-3$.

Shephard RJ. The fit athlete. Oxford: OUP, 1978: Blonstein

Proceedings of the Royal Society of Medicine 1966; $59: 649$.

4 Moncur JA. A study of fatalities during sport in Scotland. Br $\mathcal{F}$ Sports Med 1973;7:162.

* *Dr Harries replies below.-ED, $B M \mathcal{H}$.

SIR,-It is good to see Dr Sperryn shooting from the hip again. I quite agree with him that the conclusions reached by the article in Nature were not credible; I hope I made that clear. The leading article speculates on the cause of sudden (unexplained) death in athletes. Obviously death by drowning or dropping from mountainsides would not fall into that category.

Abuse of hormone drugs is nothing like as widespread in Britain as it is in the United States of America, particularly in professional sport, but it does go on. The question as to how much should be spent on dope testing and who should foot the bill deserves broader discussion than is possible here. If Dr Sperryn really believes that the problem can be answered by "eroding the incentive to cheat," then he has greater faith in human nature than I do.

It must be frustrating for the athlete who is clean to witness covert cheating by his rivals. How incredibly galling then, when it later becomes clear that such cheating has been openly supported by both coaches and team doctors. Such was the case in one event in the last Olympics, where blood doping possibly led to a medal.

Northwick Park Hospital,

MARK HARRIES

Harrow HAI 3 UJ

\section{Somatostatin and the dumping} syndrome

SIR,-The recent report by Dr R G Long and others (23 March, p 886) of a beneficial effect of somatostatin in patients with dumping is very similar to a study we presented to a meeting of the Surgical Research Society of Australàsia in October $1984 .^{1}$ In our study, unlike that of Dr Long and colleagues, somatostatin $(300 \mu \mathrm{g} / \mathrm{h})$ and placebo were administered in random order and in a double blind fashion. In our subjects somatostatin completely abolished the rise in heart rate and packed cell volume induced by an oral glucose provocation test and delayed glucose induced increases in blood glucose and serum osmolality. Dumping symptoms are notoriously difficult to quantify, and our patients did not distinguish overall symptom severity during somatostatin infusion from that during placebo infusion when expressed on a linear analogue scale. ${ }^{2}$ However, all four of our patients developed severe diarrhoea after oral glucose when given placebo, which occurred in none when they received somatostatin. On the other hand, three of the four patients developed severe abdominal pain during dumping provocation tests when they were given somatostatin-possibly because somatostatin prolonged intestinal transit and allowed distension of the small bowel by ingested (and some secreted) fluid.

We believe that the observed effects of somatostatin are attributable almost entirely to the ability of the peptide to suppress intestinal fluid secretion in response to hyperosmolar food residues reaching the gut and that it is unnecessary to speculate that somatostatin ameliorates early dumping by suppressing secretion of other regulatory peptides. Somatostatin is unlikely to exert its effect by delaying gastric emptying, since two of the four patients in our study had undergone total gastrectomy; moreover, the ability of somatostatin to suppress secretion of several regulatory peptides seems of questionable importance in the context of early dumping, since administration of these peptides to reproduce the raised circulating peptide concentrations seen in patients with dumping does not reproduce dumping symptoms in normal subjects. ${ }^{3}$ The somatostatin induced delay in the increase in blood glucose concentration is explicable in terms of the known ability of the peptide directly to inhibit intestinal absorption of glucose. ${ }^{4}$ The subsequent prolonged increase in blood glucose concentration seen both in our study and in that of Dr Long and colleagues may indeed be a result of suppression by somatostatin of the release of endogenous insulin and gastric inhibitory polypeptide and may prove of value in the treatment of late dumping. Our observations suggest, however, that somatostatin analogues with selective antisecretory activity in the gut, and without effects on motility, may be necessary to provide effective treatment for early dumping.

\section{P G REASBECK A M VAN RIJ}

Department of Surgery,

University of Otago Medical School, Dew Zealand

1 Reasbeck PG, Van Rij AM. The effect of somatostatin on dumping after gastric surgery. Aust $N Z \mathcal{Z}$ Surg 1985 (in press)

2 Revill SI, Robinson JO, Rosen M, Hogg MI. The reliability of a linear analogue scale for evaluating pain. Anaesthesia 1976;31:1191-8.

列 on gastric function in man. Lancet $1980 ; \mathrm{i}: 987-9$. somatostatin on jejunal absorption of glucose, amino acids, water and electrolytes. Gastroenterology 1980;78:26-31.

\section{Community care}

SIR,-I read your leading article on community care (16 March, p 806) with interest. I fully agree with the caution expressed in the report of the House of Commons Social Services Committee with regard to closure of hospital beds for the mentally ill and mentally handicapped. In fact I met the committee and had a stimulating discussion. But the report should not put the development of community 